\title{
Infidels-NonInfidels in Political Separation in the 2019 Presidential Election
}

\author{
Yoyok Hendarso ${ }^{1}$, Aris Munandar ${ }^{2}$ \\ \{yoyok_hendarso60@yahoo.co.id ${ }^{1}$, yarismunandar@gmail.com ${ }^{2}$ \} \\ Universitas Sriwijaya, Indonesia ${ }^{1}$ \\ Universitas Tamansiswa Palembang, Indonesia ${ }^{2}$
}

\begin{abstract}
Infidels in Indonesian terminology are people who do not believe in Allah. and His apostles (KBBI). With this meaning, infidels are used as a separate social group or separation in political contestation. In the 2019 presidential election, there were only two pairs of candidates, there are Joko Widodo-Maaruf Amin pair, and Prabowo-Sandiaga Uno pair. Thus, in a head-to-head battle like this there is a pagan-Muslim separation. For one party, the use of a pagan sentence directed at him, is an insult. This feeling of humiliation is increasingly becoming along with the increasing number of civil servants, the political atmosphere is increasingly massive using this Muslim-infidel phrase. As a democratic country, the equality of fellow citizens is a necessity. Giving a nickname that makes a citizen no longer equal to other citizens means the failure of the state creates a sense of equality towards its citizens. This paper will describe how the separation that occurred in the 2019 presidential election in social media groups in Palembang. With this article, the author will describe how the background of each actor so that this Muslim-infidel division will occur. The author will use the theories of Martin Lipset and Stein Rokkan as a reference. While the field data and case examples, the author uses several social media groups consisting of alumni from the Faculty of Social Sciences from several Universities.
\end{abstract}

Keywords: Moslem-Unbeliever, Social Cleavage, Ethnicity, Profession, Religiousity.

\section{Introduction}

The recent presidential election (2019) which has just taken place, seems to be the second round in the contestation for the race for president in the last decade. This happened because in the last two presidential elections, there were two similar candidates, there are Joko Widodo and Prabowo Subianto. In the first round, the 2014 presidential election, Joko Widodo who was paired with M. Yusuf Kalla succeeded in defeating Prabowo Subianto who was paired with Hatta Rajasa. In the second round of the presidential election, Joko Widodo as incumbent, partnered with Ma'aruf Amin, a cleric who was also the chairman of the Indonesian Ulema Council (MUI). Meanwhile, Prabowo Subianto as a challenger, is paired with Sandiaga Uno, a successful businessman. At the time of his candidacy, Sandiaga Uno resigned as Deputy Governor of DKI Jakarta Province.

Jokowi's decision to choose a partner with Ma'aruf which was announced at a restaurant in the South Jakarta area on Thursday (9/8/2018) ended various speculations as to who should accompany this incumbent as his vice-presidential candidate. The reason given by Jokowi is because this 76-year-old cleric is a wise religious figure. This election also completes the nationalist-religious separation [1]. On another occasion in Serang, Banten, Jokowi said that 
Ma'Aruf Amin was a great scholar and intellectual. Ma'aruf knows to speak sharia economics, start up, unicorn, he knows to talk decacorn, clever, smart. It was also said that the couple would unite ulama and umaroh [2].

Responding to Jokowi's decision, the Economic Observer Institute for Development of Economics and Finance (INDEF) Bhima Yudhistira assessed, Ma'ruf Amin was able to create political stability, because it was considered able to reduce the issue of ethnic and racial groups (SARA) which were now busy being debated [3]. Analysts quoted by Singapore media The Straits Times also said that Jokowi now needs a strong Islamic figure as his partner in the upcoming presidential election. This is needed not only to dispel rivals who may attack them with religious issues but also to attract conservative voters on the island of Java [4].

Indeed, in the 2014 presidential election Jokowi's figure was heavily attacked with primordial issues that smelled of SARA. Many people accused him of being of Chinese descent, his religion was questioned. Is it true that Jokowi Islam is not clear, or we can say infidel? In Vivanews, it was reported that Sujiatmi (Jokowi's mother) claimed that every morning she always recites recitation at a mosque near home. Previously Jokowi was also rumored to be Kejawen, Non-Muslim, Infidel of all kinds. It turned out that Jokowi, besides being Muslim, also had Hajj. Some of his photographs in Muslim clothes after Friday prayers were reported in the mass media [5].

In the 2014 presidential election, the debate over nuanced SARA not only took place in the real world, but also in cyberspace or the internet. This debate not only fills up writings on the internet but also on social media. During this period, the role of netizens was obvious in the campaign process, and the impact was felt. In cyberspace, netizens from both factions vigorously argued, even carrying out black campaign practices to bring down a candidate for one of the factions. Both candidates and their winning teams also realize that the use of social media is really effective in initiating public opinion and / or initiating self-image. "Cyber war" is inevitable. Both of the candidates and their winning teams understand this phenomenon very well. Strategies are arranged systematically and neatly. Presidential election in 2014 is a generation where democratic processes intersect information technology freely and wildly. Various techniques are applied, even looking really vulgar, far from the norm, full of slander and propaganda. Information is easily shared every day every minute to change someone's mindset about the presidential candidate to be elected. It seems that both factions are targeting the middle class who are actively using information technology in daily life as an effective mouthpiece to reach the wider community, even though traditional campaign practices are still being carried out [6].

This article aims to examine how regional and religious sentiments intertwine in practical politics in cyberspace. In this case the writer tries to find out how political separation that exists along with their respective backgrounds and political identities of actors who interact in cyberspace. This paper will refer to social and political separation, as the social separation used by Lipset and Rokan, Clifford Gerts as well as those which had been Sukarno's political phrase during his glory.

\section{Method}

This article is based on the fact the interaction of several actors who are members of the social media group which Whatsapp group (WAG). The author uses several WA groups that the authors themselves become part of these groups. These groups consist of: 
a. WAG SMP Negeri VI, a group whose members are a group of friends SMP Negeri VI Palembang

b. WAG Bedulur, a group whose members are friends of SMA Negeri 1 Palembang

c. WAG Sospol Politics Nian whose members are a group of college friends at FISIP Unsri Palembang.

This article is also supported by internet news, research writings in the form of journals related to social media, social divisions and political streams that once prevailed in the Indonesian political arena. The analytical framework uses the descriptive-chronological method starting from the division of ideological bases from the Old Order (1955 elections) to the 2019 Presidential Election. The emphasis is focused on the contestation of the presidential election which only consists of two pairs or head to head hence it is possible to create a polarization that refers to the struggle of two big ideologies as the political flow in the Old Order era, there are Islamic and secular polarization.

\section{Results and Discussion}

\subsection{Santri, Nobles and Gentry}

Political genre was introduced as a theoretical framework from Clifford Geertz to explain the sorting of characteristics of people in Java related to political ideology. Geertz divided Javanese people into three categorical groups namely santri, gentry, and nobles. The santri group is a group that studies Islamic teachings intensively and practices the values and traditions of Islam in their daily lives. The students usually develop in Islamic educational institutions called pesantren. The gentry group represents a society which, although it originates mostly from among Muslims, chose not to emphasize the religious aspects (Islam) in its social and political life. Gentry are more interested in adopting universal political ideas that are not related to religious teachings (Islam). While the nobles group represents the values of the Javanese aristocracy group whose religious views still carry Hindu values. They usually occupy positions of government structure and hold authoritative powers [7].

\subsection{Soekarno and Nasakom}

Soekarno in 1926 wrote in the Soeloeh Indonesia Muda magazine about his political views such as Nationalism, Islamism and Marxism. This idea was inseparable from Sukarno's strategy of how Indonesia was free from the shackles of colonialism. Soekarno further wrote:

"Learning, looking for the relationship between the three characteristics, proving, that these three directions in a colony are useless against each other, proves also, that these waves can work together into a single wave that is great and strong, a typhoon that cannot be held lunge, that's the obligation that we all have to shoulder"...

"Somehow the achievement of that union; somehow the union seemed to be; but still, that the ship that takes us to independent Indonesia, is the unity ship! ".

Soekarno's idea was how he saw the potential that existed at the grassroots of Indonesian society which could be used to repel invaders. In subsequent developments, these three concepts are more commonly referred to as Nasakom, as an acronym for nationalism, religion and 
communism. How views or ideologies emerge in a person cannot be separated from the motivation, nature and characteristics of individual choices. Pervin \& John (1997) say that nature produces predisposition to think, feel or act in a certain pattern regarding people, events and situations. It can be interpreted that Sukarno's ideas about nasakom were his way of seeing how his people were based on what he saw and what he felt in his struggle with the Indonesian people in various social layers during the colonial period.

This Nasakom in practice became Sukarno's policy after he "take over" the authority through the presidential decree of 1959 after a committee for the constituting of the law (constituent) was also not finished in constituting new laws after the proclamation of independence. With this decree, Sukarno personally held almost all power in his hands. With this presidential decree, Indonesia again used the UUD 945 as a constitution. The UUD 1945, which articles contain more general rules, gives Sukarno the flexibility to translate them privately. And in fact, the concept of Nasakom which was instigated by its civil servants was more widely used by the Indonesian Communist Party. This situation is in accordance with history, inviting more enemies to Sukarno personally. At the end of his authority, Sukarno was uprooted by Islamic forces which were side by side with the army who were envious of the freedom possessed by the Indonesian communist forces.

State relations in the case of politics and religion continue to co-exist in their respective roles. Nonetheless we understand that religion and the state do not always play a positive role in the political process. The atmosphere of the 2014 election and approaching the 2019 election for example, the issue of religion is really dense coloring politics in Indonesia. Not infrequently, the issue of religion is "fried" into a vehicle to win a government seat. In the face of the 2019 elections we must remain vigilant in the exposure of politicized religion. It is crucial to define religion and the state in an ideal position, so that the 2019 elections run well and are not conducive to getting out of the spirit of democracy for the country [8].

On the other hand, the use of religion as a political instrument to gain power in elections is rife lately. Religion as something sacred is used as a powerful weapon to destroy society through differences in belief. For the reason that religion is something sacred and personal in nature it makes it easy to politicize regarding this sensitive issue. Religion as something that is sensitive makes everything that works with it becomes more emotional. This emotional involvement is built by belief in something celestial. The politicization of religion has been used as a black politics that manipulates one's understanding and knowledge of religion by means of propaganda that intends to influence religion/belief in its efforts to bring interests into a political agenda. What is feared is that religion loses its noble values when associated with politics or politicized (smudged). The rejection of the politicization of religion is one form of efforts to glorify religion and prevent the destruction of the noble values that exist in a religion and to maintain the diversity and integrity of our nation [9].

While talking about religion and politics, Gunter W. Remmling (1976) sees the two as two separate forms but both carry social roles in society. Religion with the moral value of civil servants who play role as patrols of the rules, harmonization, and patrols of norms and values in society. On the other hand, politics is synonymous with power and the role of regulation. In Herbert Spencer's Thesis, politics and religion play the same role, which is related to regulating and restraining. Related to institutional studies, according to Spencer, religion and politics have a role in society as institutions to regulate and defend the values held in society [8].

The relation between religion and politics is exemplified by Kopko [10] that religion has a correlation with participation. Kopko [10] takes the example of the Mennonite Church community in America. According to Kopko [10], Mennonite Church is not concerned with political activities due to the fact that politics is more mundane. In his research, Kopko found 
as much as 48 percent of church people who identified themselves as Mennonites did not like political activities [10]. Cultural diversity (Multiculturalism) in Indonesia causes the Indonesian nation to be easily divided. Afghanistan as a country with only 8 tribes has various conflicts, moreover Indonesia which has thousands of tribes in it. Multiculturalism is a term used to describe views about the variety of life in society in the world both regarding the values, systems, culture, habits, and politics that they profess. Multiculturalism can be understood as a worldview embodied in "politics of recognition" [9].

Taufik Abdullah saw 1920's until 1940's as a decade of ideology. Strategies and ideologies are created and debated. Groups of Islamic nationalism and secular nationalism are diametrically opposed [11]. Through the BNO, in the discourse of the Islamic state in 1940, NU showed a religious view that was oriented towards legal-formal by supporting Dar Al-Islam while opposing the secularism that was advocated by Sukarno and his group. Nevertheless, in the 15th Congress, a closed meeting of 11 prominent clerics decided that Sukarno was a person who qualified as president. With the abundance of Islam scientific, NU is able to handle between legal-formal views and political realities, without sacrificing Islam. In this context NU's views on Pancasila can be questioned by Indonesian Muslim minority groups. M. Natsir considers that the matters of state are basically an integral part of Islam, which contains a philosophy of life or ideology such as Christians, Fascists or Communism [11].

M. Natsir stated emphatically that Indonesia is an Islamic state, although it is not mentioned in the constitution, Islam is the state religion. For him de facto certainly shows that Islam is recognized as a religion and a model of the soul of the Indonesian people, even more than that the problem of statehood in Indonesia cannot be separated from religion [11].

The increase in religious radicalism has much to do with the fact that there are increasingly various interpretations, understandings, streams, and even sects within (in) one particular religion. According to Azyumardi Azra, in Islamic circles, religious radicalism originated a lot from [12]:

a. Literal religious understanding, fragmentary to the verses of the Quran. Such understanding hardly gives room for accommodation and compromise with other Muslim groups which are generally moderate, and therefore become the mainstream of the Ummah. This group of Muslims who have understood this has emerged since the time of al-Khulafa 'al-Rashidun the fourth Ali ibn Abi Talib in the form of the Khawarij who were very radical and committed many murders against Muslim leaders whom they had declared "infidel".

b. Misinterpretation of the history of Islam combined with excessive idealization of Islam at any given time. This can be seen in the views and movements of the Salafis, moreover in the extremist spectrum such as the Wahabiyah that emerged in the Arabian Peninsula in the late 18 th century until the 19th century and continues to emerge today. The main theme of these Salafi groups and cells is the purification of Islam, which is to cleanse Islam of religious understanding and practicing which they view as 'heresy', which they often do by means of violence. With such religious understanding and practice, these radical groups and cells 'narrow down' (splinter) from mainstream Islam which holds domination and hegemony theological authority and religious law and at the same time religious leadership.

While Rubaidi describes the five characteristics of the radicalism movement. First, making Islam as the final ideology in regulating individual life and political order in the state. Secondly, the Islamic values that embraced adopt their sources - in the Middle East - as they are without considering social and political developments when the Quran and the hadith are present on this 
earth, with the local realities of the present. Third, due to the fact that attention is more focused on the text of the Quran and hadiths, this purification is meticulous to accept all non-Islamic cultures (Middle Eastern culture) including being careful about accepting local traditions for fear of interfering in Islam with heresy. Fourth, reject Non-Middle Eastern ideologies including Western ideologies, such as democracy, secularism and liberalism. Once again, all the rules set must refer to the Qur'an and the hadith. Fifth, this group movement is often contradictory with the wider community including the government. Therefore, sometimes ideological and even physical friction occurs with other groups, including the government.

In his research on radical groups in Solo, Munip [12] found that this group was formed from a thought that was fundamental-radical and allergic to various types of discourse originating from the West. Thus, the mindset developed is "Islam vs. West". While groups that do not use violence to achieve their ideological goals develop symbolic discourse by disbelieving other groups that are not in line with their ideology. They also consider socio-political, secular law will not lead to socio-cultural, economic, legal, and political improvements for Muslims [13].

\subsection{Personal Identity}

Political identity according to Widayanti (2009) is another name for bio-politics and political-diversity. Bio-politics is based on differences arising from bodily differences [14]. Identity according to Jeffrey Week is related to belonging about equality with a number of people and what distinguishes one person from another. Jeffrey Week's opinion emphasized the importance of identity for each individual and for a group or community. Meanwhile, Anthony Giddens defines self-identity as what we think about self [15]. Further said, what we think about ourselves is changing from one situation to another according to time and space. This view lies behind Giddens in referring to identity as a project, that is, something that we create, something that is always in the process, a movement forward rather than something that comes later.

Agnes Haller draws the definition of political identity as a political concept and movement whose focus is on difference as a major political category. Like it or not, indeed political identity in Indonesia is still in great demand by political elites to win political competition. One of their distinguishing identities is religion. For example, talking about the electability of Jokowi-Maruf Amin, at the beginning of their decision to become a presidential candidate, Jokowi's electability decreased, moreover decreased in non-Muslim voters, but increased in Muslim voters. Islam as the majority religion in Indonesia seems to be a vehicle for elites to win political competition. With regard to the electability, Jokowi's electability has gradually increased due to Muslim voters. In August 2018 it was recorded 52.2\%, October increased to 52.6\% and beginning of November $54.1 \%$ [8].

\subsection{Cyber Society}

The emergence of cyber society as a result of the development of communication technology has made the pattern of communication undergo changes. Communication culture by cyber society involves processes of interaction using symbols, this interaction which we call symbolic interaction. In the process the cyber community shapes its own culture and communication patterns. Through information technology they convey messages in a group formed through the used social media. The messages are delivered in the form of symbols that are given meaning; this makes cyber communication has various meaning due to the fact symbols are more meaningful than verbal messages. There are two crucial goals in the relations between cyberspace and democracy, there are 1) activism and 2) preservation. The meaning of activism 
refers to the notion of the formation of political movements while the meaning of preservation that is more seen that cyberspace as a democratic fied [16].

Social media is further described as an ideal tool and information base to find out public opinion about policies and political positions, in addition to build community support for politicians who are campaigning. Numerous studies show that politicians around the world have adopted social media to build relationships with constituents, engage in direct dialogue with the public and form political discussions. The ability to create a dialogue space between politicians and the public and attract the interest of new/young voters makes social media increasingly crucial for politicians [8].

In this article the author uses infidel as keyword which is a derivative of the theories mentioned above. When someone use the term infidel, the author defines the informant identifies himself as Islam, and the interlocutor identifies himself as a secular group.

In the author's count, there are more than 150 posts that use the term "infidel". With reference to the 56 passive and active members of these WAG members, the author identified 16 members who quite often posted the word "infidel". How is the regional background and occupation of WAG members who post the word "infidel", the author summarizes in the following table:

\begin{tabular}{|c|c|c|c|c|c|c|c|}
\hline \multirow[t]{2}{*}{ No } & \multirow{2}{*}{ Name } & \multicolumn{2}{|c|}{ Infidel word means } & \multirow{2}{*}{$\begin{array}{l}\text { Political } \\
\text { Choice }\end{array}$} & \multirow{2}{*}{ Origin } & \multirow{2}{*}{ Occupation } & \multirow{2}{*}{$\begin{array}{c}\text { Politics } \\
\text { Background }\end{array}$} \\
\hline & & Charge & Response & & & & \\
\hline 1 & Kemas & & $\sqrt{1}$ & 01 & Palembang & Entrepreneur & Hanura \\
\hline 2 & Andiek & $\sqrt{ }$ & & 02 & Palembang & $\begin{array}{l}\text { PMA } \\
\text { employees }\end{array}$ & - \\
\hline 3 & Edo & $\sqrt{ }$ & & & $\begin{array}{l}\text { Arab } \\
\text { Descent }\end{array}$ & $\begin{array}{l}\text { Employees of } \\
\text { State-Owned } \\
\text { Enterprises } \\
\text { (BUMN) }\end{array}$ & -- \\
\hline 4 & Erko & $\sqrt{ }$ & & 02 & Minang & Seller & -- \\
\hline 5 & Aris & & $\sqrt{ }$ & 01 & Palembang & Lecturer & -- \\
\hline 6 & Juned & $\sqrt{ }$ & & 02 & Minang & $\begin{array}{l}\text { Employees of } \\
\text { Regional- } \\
\text { Owned } \\
\text { Enterprises } \\
\text { (BUMD) }\end{array}$ & -- \\
\hline 7 & Basyet & & $\sqrt{ }$ & 01 & Palembang & $\begin{array}{l}\text { Contractor of } \\
\text { a BUMN }\end{array}$ & Caleg PDI-P \\
\hline 8 & $\begin{array}{c}\text { Syahda } \\
n\end{array}$ & $\sqrt{ }$ & & 02 & Palembang & Businessman & -- \\
\hline 9 & Gindo & & $\sqrt{ }$ & 01 & Batak & Aktivist & -- \\
\hline 10 & $\begin{array}{c}\text { Mulyon } \\
\mathrm{o}\end{array}$ & & $\sqrt{ }$ & 01 & Java & Aktivist & Nasdem \\
\hline 11 & Fitrah & $\sqrt{ }$ & & 02 & Minang & $\begin{array}{l}\text { Contractor of } \\
\text { Regional } \\
\text { Spending } \\
\text { Budget } \\
\text { (APBD) }\end{array}$ & Caleg PAN \\
\hline 12 & Firdaus & $\sqrt{ }$ & & 02 & Minang & Grab Driver & -- \\
\hline 13 & Mistur & $\sqrt{ }$ & & 02 & Palembang & Civil Servant & -- \\
\hline 14 & Ade & $\sqrt{ }$ & & 02 & Java & Civil Servant & -- \\
\hline 15 & Iwan & $\sqrt{ }$ & & 02 & Palembang & Civil Servant & -- \\
\hline 16 & Afiz & $\sqrt{ }$ & & 02 & Palembang & $\begin{array}{l}\text { Employees of } \\
\text { BUMN }\end{array}$ & -- \\
\hline
\end{tabular}


From the table above it can be seen that of the 16 members of WAG who were actively discussing, there were 11 members who used the term "infidel" in the connotation of attacking and five members who used the term "infidel" in the defending connotation. As from various previous descriptions, those who often use the term infidel, are actually more focused on the Presidential Candidate number 01, Joko Widodo. Also, from the data above, 11 WAG members who often use the word infidel in the context of attacking, did not choose Joko Widodo, but instead chose pair number 02 it is Prabowo-Sandiaga Uno pair.

Based on sociological background, the WAG members in this article consist of 8 Palembang people, 4 Minang people, 2 Javanese, 1 Batak person and 1 Arab descendant. While in terms of profession, there are 4 who work in BUMN/D, 2 contractors in BUMN/D, 3 civil servants, the rest are employees, lecturers and other independent occupations.

From the data above, 5 out of 8 members from Palembang ethnic group chose PrabowoSandiaga Uno pair, and 3 others chose Jokowi-Ma'aruf pair. While in terms of occupation, it is also seen, all WAG members who work as civil servants also choose Prabowo-Sandiaga Uno pair. Likewise, all with a background in BUMN/chose Prabowo-Sandiaga Uno.

The interesting thing from this basic data is that $100 \%$ of members of Minang ethnic background and who work in BUMN/D often use the word infidel in the context of attacking and choosing the pair of Prabowo-Sandiaga Uno. From the posts in WAG also discussed the historical factor of Indonesia, such as PRRI/Permesta rebellion. As it is known on the island of Sumatra, resistance to the central government (Jakarta) is greater in West Sumatra and has led to military action between political and armed forces between the central government.

How tragic the "civil war" in West Sumatra at that time, was told by Hanna (1959) as the atmosphere of the war led to anarchic acts, brutal acts that caused many victims to fall as a result of violence, as well as abuse of military authority, terror, rape, breaking into people's homes, to the point of torture and murder. Even more tragic, so many young Minang lost (generation between generation 45 and 66) because most of the population of West Sumatra is connected with PRRI. The CIA, which had initially assisted the PRRl, gradually withdrew its support and turned to the central government, which sent its troops periodically from its forces in Java. According to reports the government had killed 983 people, 1,695 injured and 154 missing, while 6,373 PRRl were killed, 1,201 injured and arrested and 6,057 surrendered [17].

Government policy does not always benefit all parties. As a political choice, policy can benefit one party and disadvantage the other party. In mid-2016, the government released a plan to rationalize civil servants (PNS). This plan draws the reaction of Korpri, the sole vehicle for civil servants, to be involved in the formulation of the policy. Chairperson of the Korpri National Management Council (DPN), Zudan Arif Fakrullah, asserted, a lawsuit to the State Administrative Court (PTUN) of civil servants who objected to the rationalization policy must be anticipated. "Korpri will advocate for civil servants in accordance with article 126 of the Civil Servants Law if this government policy disadvantage civil servants"[18]. Even in spite of the fact that it is normative and hopes that Korpri members remain calm with this government plan [1][19]. While saying that the Korpri will improve the quality of the state apparatus [20], however still this has caused unrest among the PNS corps. Therefore, it is not surprising that with a policy plan like this, Jokowi has the antipathy of voters from among civil servants. 


\section{Conclusion}

The use of the word "infidel" in the whatsapp group in this study is not related to various actions or fears of radical movements that are rife lately. Users of the word "infidel" in the regional category, namely the Minang tribe are more on the historical background of the PRII/Permesta events which are the historical setting of the Minang community. Indeed there has been no in-depth research on whether the Minang migrants in Palembang had anything to do with the incident, or whether the Minang migrants in Palembang were migrations from West Sumatra related to the incident, but in fact members of the whatsapp group in this study showed antipathy toward presidential candidate Jokowi. This cannot be separated from the main party supporting Jokowi namely PDI-Perjuangan. When traced back, the PDI-P and its chairman Megawati could not be separated from the big name behind him, namely Soekarno. As is known, it was President Soekarno who ordered the suppression of the Permesta PRRI resistance movement, causing many victims and prolonged trauma to the Minang people.

Antipathy towards presidential candidate Jokowi emerged from the civil servants. Even in spite of the fact that the civil servants of this country also often post the word "infidel", but this also has nothing to do with the radicalism movement, but rather to rational matters related to the convenience of working.

When looking at the background of whatsapp group members with Minang ethnic background as traders / businessmen, plus civil servants who do not support the Jokowi presidential candidate, the author concludes that the flow of politics in the 2019 presidential election is still valid. In accordance with Geertz's findings that the santri community is represented as a merchant society and civil servants as nobles who work in the government bureaucracy. However, the gentry's factor is still not represented in this study. This is due to the fact that Jokowi's supporters in the Whatsapp group in this study are educated people and do not neglect the religious life of their civil servants as Muslims.

\section{References}

[1] Kompas, "Ini Alasan Jokowi Pilih Ma’ruf Amin Jadi Cawapresnya." [Online]. Available: https://nasional.kompas.com/read/2018/08/09/18381791/ini-alasan-jokowi-pilih-maruf-aminjadi-cawapresnya?page $=$ all.

[2] Detikcom, "Di Banten, Jokowi Bicara Alasan Pilih Ma'ruf Amin: Beliau Tahu Unicorn." [Online]. Available: https://news.detik.com/berita/d-4481340/di-banten-jokowi-bicara-alasanpilih-maruf-amin-beliau-tahu-unicorn .

[3] "No Title." [Online]. Available: https://www.liputan6.com/bisnis/read/3615089/jokowi-tunjukmaruf-amin-jadi-cawapres-ini-prediksi-pengamat-ekonomi,. [Accessed: 23-May-2019].

[4] "No Title." [Online]. Available: https://www.cnbcindonesia.com/news/20180810115118-427958/ini-kata-analis-di-media-asing-soal-jokowi-pilih-maruf-amin. [Accessed: 25-May-2019].

[5] R. Ikawati, "CITRA KESALEHAN DALAM POLITIK: STUDI TENTANG PREFERENSI MASYARAKAT TERHADAP CAPRES-CAPRES DALAM PILPRES 2014,” RIGHT J. Agama dan Hak Azazi Mns., vol. 4, no. 2, 2017.

[6] M. Y. Madrah and M. Mubarok, "NETIZEN DALAM KAMPANYE PILPRES RI 2014," Interak. J. Ilmu Komun., vol. 7, no. 1, pp. 16-25.

[7] A. G. Herdiansah and H. Ismiati, "PEMBELAHAN IDEOLOGI, KONTESTASI PEMILU, DAN PERSEPSI ANCAMAN KEAMANAN NASIONAL: SPEKTRUM POLITIK INDONESIA PASCA 2014?," JWP (Jurnal Wacana Polit., vol. 2, no. 1, 2017.

[8] S. \& DangXuan, "aGaMa daN NEGara: PolitiK idENtitas MENUJU PilPrEs 2019," $J$. komunikasi, ISSN 1907-898X, vol. 8, no. 1, 2013.

[9] S. Faridah and J. Mathias, "Politisasi Agama Pemecah Keutuhan Bangsa dalam Pemilu," in 
Seminar Nasional Hukum Universitas Negeri Semarang, 2018, vol. 4, no. 03, pp. 489-506.

[10] K. C. Kopko, "Religious Identity and Political Participation in the Mennonite Church USA," Polit. Relig., vol. 5, no. 2, pp. 367-393, 2012.

[11] M. A. Najib, "NU, SOEKARNO DAN STAAT ISLAM: WACANA NEGARA ISLAM DALAM BERITA NAHDLATOEL OELAMA (BNO)," Ahkam J. Huk. Islam, vol. 5, no. 1, pp. 163-184, 2017.

[12] A. Munip, "Menangkal radikalisme agama di sekolah,” J. Pendidik. Islam, vol. 1, no. 2, pp. 159$181,2012$.

[13] N. Kafid, "Dari Islamisme ke 'Premanisme': Pergeseran Orientasi Gerakan Kelompok Islam Radikal di Era Desentralisasi Demokrasi,” Masy. J. Sosiol., pp. 57-79, 2016.

[14] M. Habibie, “'Analisa Politik Identitas di Indonesia," Fak. Ilmu Sos. dan Ilmu Polit. Univ. Mulawarman, 2017.

[15] Y. H. Trinugraha, "Politik Identitas Anak Muda Minoritas: Ekspresi Identitas Anak Muda Tionghoa melalui Dua Organisasi Anak Muda Tionghoa di Surakarta Pasca Orde Baru,” J. Stud. Pemuda, vol. 2, no. 2, pp. 172-186, 2013.

[16] W. R. Jati, "Cyberspace, Internet, dan Ruang Publik Baru: Aktivisme Online Politik Kelas Menengah Indonesia," J. Pemikir. Sosiol., vol. 3, no. 1, pp. 25-35, 2016.

[17] M. Z, Dekade Pergolakan Daerah Mendekati Isu-isu Konflik Pusat-Daerah dalam Perspektif Pembangunan Nasional Tahun 1950-an. Jakarta: Seminar Pembangunan Nasional sebagai Totalitas Pembangunan Daerah, Dewan Perwakilan Daerah (DPD) bekerja sama dengan Panitia Satu Abad Mr. Sjafruddin Prawiranegara.

[18] "No Title." [Online]. Available: https://www.beritasatu.com/nasional/368649/korpri-siappasang-badan-jika-rasionalisasi-pns-merugikan,.

[19] "No Title." [Online]. Available: http://pontianak.tribunnews.com/2016/06/09/isu-rasionalisasikorpri-serukan-pns-tetap-tenang,.

[20] "No Title." [Online]. Available: https://nasional.tempo.co/read/778390/korpri-rasionalisasitingkatkan-kualitas-aparaturnegara/full\&view=ok, . 